\title{
Modelling benthic invasion by the colonial gastropod Crepidula fornicata and its competition with the bivalve Pecten maximus . 1. A new OD model for population dynamics of colony-forming species
}

\author{
Ménesguen Alain ${ }^{1,}{ }^{*}$, Grégoris Thomas ${ }^{1}$ \\ ${ }^{1}$ Ifremer, Centre de Bretagne, Unité DYNECO/Laboratoire LEBCO, 29280 Plouzané, France \\ * Corresponding author : Alain Ménesguen, email address : amenesg@ifremer.fr
}

\begin{abstract}
:
The north-American marine gastropod Crepidula fornicata (Linné 1758), commonly called slipper limpet, has been introduced accidentally in Great Britain, along with American oysters (Crassostrea virginica) at the end of the 19th century. Its spreading, enhanced by oyster transport and international shipping, turned into invasion of a lot of benthic grounds along the North-European coasts. When local conditions are favorable to larval confinement and adult growth, the invasion by very dense populations may deeply change initially sandy or muddy benthic communities into similar "slipper limpet communities". Competition for space eliminates several species of native infauna, and hampers the survival of some epibenthic bivalves such as the scallop Pecten maximus. As the clogging of dredges by superabundant slipper limpets drastically limits scallop fishing, some insight in the future distribution and abundance of both species (Crepidula and Pecten) seems necessary, especially in the English Channel where the scallop is intensively harvested. An original model, storing in a "intraspecific matching matrix" the numbers of pairs of aged animals present in the slipper limpet chains, has been developed to take into account the year-class association and stack formation specific to Crepidula fornicata. Then, an "interspecific matching matrix" component has been added to that "intraspecific matching matrix" in order to describe the simple year-class structure of the scallop along with the age distribution of slipper limpets stuck on scallop shells and forming the base of chains. Such a model can explore the dynamics of both populations at a secular time scale. This first part of work details the OD-behavior of the populations, alone or together, on $1 \mathrm{~m}^{2}$ benthic area. As far as the scallop is concerned, the fact that class 1 cannot recruit in dense populations until the death of old animals has freed some place induces a limit-cycle, with a 11 years period, and a large amplitude. On the contrary, in the case of the slipper limpet, because of the constant possibility for class 1 to recruit on the top of existing colonies, even if the bottom coverage is total, the population reaches a stable steady state abundance, without significant oscillations. Competition for space between the two species does not alter significantly the slipper limpet, whereas it lowers the mean abundance and alters (by damping and slowing down) the limit cycle of the scallop.
\end{abstract}




\section{Highlights}

- A novel "matching matrix" is proposed in order to simulate the age structure of animal colonies. A OD model is built to compute the annual modifications of this "matching matrix", taking into account the competition for bottom space. I It simulates the invasion of a benthic area by the chain-forming gastropod Crepidula fornicata and locks on a stable chain length distribution. The model can be adapted to simulate simultaneously non colonial species and their competition with the invasive, chainforming species. Invasion by the colonial gastropod lowers the abundance of the harvested bivalve Pecten maximus and damps its natural limit cycle.

Keywords : Crepidula fornicata, Invasive species, Benthic gastropod, Colony model, Matching matrix, Pecten maximus, Competition, Population dynamics, Limit cycle 


\section{Introduction}

The benthic, marine gastropod Crepidula fornicata (Linné 1758), belonging to the family Calyptraeidae and commonly called slipper limpet, is native of the North-American Atlantic coast, but has been introduced accidentally in Great Britain, along with American oysters (Crassostrea virginica) at the end of the $19^{\text {th }}$ century. Oyster transport between different farms and the increase of international shipping over recent decades have spread this initial inoculate throughout the northern hemisphere. Blanchard (1996) shows in his historic compilation that, since the first observation on oyster beds in Liverpool Bay in 1872, the species has become an "oyster pest" along the coasts of the southern half of the UK, western France, Belgium and the Netherlands. In the English Channel, colonization moved westward, from Portsmouth in 1913 to Start Point (Devon) in 1960. But the Thames estuary also has been heavily infested since the 70's. On the Belgian and Dutch coasts, the slipper limpet was observed since the 20's, but remained confined in sheltered harbours, as Ostende or in estuaries as the Scheldt one. The closure of Lake Grevelingen in 1971 gave a formidable opportunity to the gastropod colonies to invade the benthos of this confined area. In France, whereas only rare specimens were observed before the World War II in the oyster beds of the northern half of the bay of Biscay, more and more specimens were collected at the end of the 40's, on mussel beds in Normandy, on scallops in the bay of Brest. This sudden introduction in several places was caused by animals fouling the hulls during Allied shipping operations, coming either from Great-Britain or directly from the USA (Blanchard, 1995). The subsequent spread along the Atlantic coast was facilitated by oyster transfers (Marteil, 1963 and 1965), but these Atlantic populations seem to have rapidly reached an equilibrium, e.g. around 5000 tons in Marennes-Oléron bay (Sauriau et al., 1998). On the contrary, the populations occupying the western French side of the English Channel may continue their spreading since the 250,000 tons assessed in the bay of Saint-Brieuc by Hamon and Blanchard (1994) and the 214,000 tons recorded in the bay of Mont-Saint Michel by Ehrhold et al. (1998).

The invasive character of this species is commonly linked to some of its biological characteristics. Individuals are protandric hermaphrodites, and build stable colonies by stacking successive age-classes, with the youngest male on top and the oldest female at the base of the colony. These quasi-motionless piles can totally cover the bottom, and ensure their growth by filtering plankton in the water bottom layer. Even if such assemblages can provide refuge to a well diversified benthic community, they cause a progressive standardization of the benthic communities (Hamon et al., 2002). Potential predators sampled within limpet beds (crabs, flatfishes, asterids, drilling gastropods) do not seem to feed intensively on the colonies. The question then 
arises about the ultimate capacity of this gastropod to invade a large part of the European coastal zone and deeply modify its various benthic assemblages.

This article proposes an original approach to colony modelling, and applies it to a OD problem (i.e. building an assemblage of colonies over a small ground surface). A sensitivity test to the larval input shows the crucial role of this biological parameter in the settlement success. Then, the model is used in its "no colonial" mode and applied to an exploited bivalve, the scallop Pecten maximus, which has suffered from the invasion by the slipper limpet. Competition and phoretic cooperation between slipper limpet and scallop is finally tested in a unique, merged model of both species. A second article will distribute this OD model over the Bay of BiscayEnglish Channel continental shelf in order to simulate the invasion by slipper limpet and the competition between the two species.

\section{Material and methods}

\subsection{The colony model}

\subsubsection{The "matching matrix"}

Classical population dynamics assumes that individuals belonging to various age-classes are independent from each other, so that they occupy randomly the physical space left available. Topological information in population models appears in two research fields: the simulation of the dynamics of animal swarms (Parrish and Edelstein-Keshet, 1999), and the simulation of the topology of growing plants (Lindenmayer, 1968). Whereas the first domain focuses on emergent properties of a cloud of similar individuals, the L-system approach used by the second domain is fundamentally based on local properties of cell division, not on the age of individual cells. As no model seems to have been built to simulate a non-random static topology of species age-classes, we propose here to tackle with colonies as ordered chains of characters taken among an alphabet of $\mathrm{p}$ letters (i.e. the $\mathrm{p}$ age classes). As the full determination of all the colony assemblages that can be made by re-assorting $\mathrm{N}$ individuals belonging to $\mathrm{p}$ age-classes is a very complex combinatorial task, we will limit our description of the colony topology to the only census of all the present pairs of contiguous animals. We then define the "matching matrix" of the population as the $(p+1) x(p+1)$ table (with the rows and the columns numbered from 0 to $\mathrm{p}$ ) containing in cell $(\mathrm{i}, \mathrm{j})$ the number of individuals of age $\mathrm{i}$ surmounted by an individual of age $\mathrm{j}$ which are to be found in colonies occupying a unit surface of sea bottom. In the case of the slipper limpet, the upper right triangle of the matrix will be empty, because animals cannot surmount individuals younger than themselves. In spite of some observed cases of late individuals of a year class surmounting an early 
individual of the same year class, we will also admit that animals can only be surmounted by individuals strictly younger than themselves, i.e. that the diagonal terms of the matching matrix remain null. The first row (numbered 0) of the matrix is devoted to animals which rest on the sea bottom, whereas the first column (numbered 0) inventories the animals that are not surmounted by any other individual, i.e. animals located at the top of the colonies; the cell $(1,0)$ gives the total number of individuals of age 1 . An interesting property of such a matching matrix is that the vector containing the sums of the $(p+1)$ rows is identical to the one containing the sums of the $(\mathrm{p}+1)$ columns. As an example, the "matching matrix" of a population corresponding to a single colony is given in Fig.1 (left panel). The number of couples appearing in the "matching matrix" depends on the elemental benthic area chosen for this OD model; here we have chosen $1 \mathrm{~m}^{2}$. But as this elemental area stands for a wide region in the field, we allow counts in the "matching matrix" to be real numbers, not exclusively integers; this prevents from a too quick elimination of rare age-classes.

\subsubsection{The annual modification of the "matching matrix"}

We consider that the colonization of the bottom by the slipper limpet is a first order Markovian process having a time step of one year. Annual changes in the abundance of the p age classes are the result of entrance of pelagic larvae, which transform into benthic first age class animals during the recruitment process, and losses of benthic animals. Because only juvenile males can crawl to a suitable site for attachment, whereas animals of 2 years and more are incapable of further movement (Fretter and Graham, 1981), we have considered adults as quasi-immobile, so that no immigration or emigration of benthic animals is taken into account.

The entrance of young animals by settling of pelagic larvae can be either internal to the system (i.e. larvae come from eggs laid by the animals present in the domain) or external (i.e. larvae come from eggs laid by animals outside of the domain) or both. Despite a large period of spawning spreading from March to September in Brittany (Marteil, 1963), the populations of Crepidula fornicata in the bay of Brest have shown during four consecutive years 3 to 4 peaks of hatching per year, the main one occurring in May or June (Richard et al., 2006). In Wales, Bohn et al. (2012) have also observed the main peak of larvae in water in June. Because of the annual time step of our model, we have gathered the possible successive hatching periods in a single one per year and we have used an allometric power law for fecundity dependence on size (Richard et al., 2006). Class 1 individuals ordinarily recruit on existing colonies (Cahill , 2015). In the simplest version of our model, we allow only one recruit per top animal of an existing colony, whereas in an improved version we allow larvae to fix on existing animals, whatever their position in the colony. But larvae can also fix on another benthic substrates 
(rocks, shells of dead molluscs...). As they prefer settling on living benthic slipper limpets (Bohn et al., 2013), we assign a fitness coefficient $\alpha<1.0$ to bare grounds for slipper limpets colonization. Whatever its final target, this recruitment process is supposed to have a probability proportional to the fraction of ground area covered by the target area. The recruitment probability on individuals occupying the top position of existing colonies has been set as the ratio (bottom area covered by colonies : total bottom area), whatever their age (see Discussion). The recruitment probability on free bottom will be ( $\alpha$ x remaining free bottom surface : total bottom area), with $\alpha<=1.0$.

The loss of animals will be considered as only due to mortality. Because of the lack of specific studies on the age dependency of mortality rate, a rate constant $(\mathrm{m})$ over the whole life has been taken for the model. The death of an individual located between the basic and the top animals of a colony will cut this colony into two shorter colonies, so the model creates a new top individual and a new basic individual.

The colony structure may be affected by accidents, especially shocks from dredges which can split a chain into two new shorter chains. The model allows a probability $\mathrm{b}\left(\mathrm{b}<1.0 \mathrm{y}^{-1}\right)$ to this event and, as for individual mortality, reallocates a new top individual and a new basic individual in this case.

Even if colonies seem to be quite motionless, some weak rearrangement of broken chains can be introduced in the model, according to a probability a $\left(\mathrm{a}<1.0 \mathrm{y}^{-1}\right)$.

A crucial problem in a model of an invasive benthic species is the treatment of competition for space. As slipper limpets are really able to occupy the total available ground area, we attributed to every basic animal of colonies a "vital area" equal to its real ventral surface, which is obtained from a von Bertalanffy growth curve (Blanchard et al., 2001). When the growth of animals at the basis of colonies, as well as new recruitment on bare substrate lead to a total "vital area" overshooting the elemental ground area of the model, a random kill of basic individuals is done until the total coverage of basic animals goes back under the maximum area available.

Finally, this model requires p.(p+1)/2 state variables, one for the annual abundance of each pair (called "Crepidula fornicata $a_{\mathrm{i}, \mathrm{j}}$ " or $\mathrm{Cf}_{\mathrm{i}, \mathrm{j}}$. The equations for the inner pairs of colonies $(\mathrm{i}>1, \mathrm{j}>1)$ have the same generic form (Eq. 1), whereas specific equations are needed for bottom animals (Eq. 2), for top animals (Eq.3) and for new recruits (Eq. 4 and 5). The significance and the value of the various parameters used in these equations are given in Table 1.

Equation for inner pair $(i, j) i$ and $j>1$ :

$C f_{i, j}^{n}=(1-m)^{2} \cdot(1-b) \cdot C f_{i-1, j-1}^{n-1}+a \cdot C f_{i-1,0}^{n-1} \cdot C f_{0, j-1}^{n-1}$

Equation for basic individuals $(i=0)$ 
$C f_{0, j}^{n}=(1-m-a) \cdot C f_{0, j-1}^{n-1}+(b+m) \cdot(1-m) \cdot \sum_{i=j}^{p} C f_{i, j-1}^{n-1}$

Equation for top, non-recruit, individuals $(\mathrm{j}=0$ and $\mathrm{i}>1)$

$C f_{i, 0}^{n}=(1-p r) \cdot(1-m-a) \cdot C f_{i-1,0}^{n-1}+(b+m) \cdot(1-m) \cdot \sum_{j=i}^{p} C f_{j, i-1}^{n-1}$

Equation for recruitment on existing top individuals $(j=1$ and $i>1)$

$C f_{i, 1}^{n}=\operatorname{pr} \cdot(1-m) \cdot C f_{i-1,0}^{n-1}$

Equation for recruitment on bare substrate $(i=0$ and $j=1)$

$C f_{0,1}^{n}=p r . n l a r v a e \cdot \alpha \cdot b a r e_{-} a r e a$

Equation for pelagic spat release and survival

nlarvae $=\left(\sum_{i=1}^{p}\left(f_{i} \sum_{j=0}^{i-1} C f_{i, j}^{n-1}\right)\right) . s / d$

The probability pr of recruitment on favorable substratum is computed every time step following Eq. 7.

$p r=\min [($ bottom_larvae/top_animals $) \times($ total_basic_animals_area/total_bottom_area), 1.0] (Eq. 7)

\subsubsection{Reconstructing colony assemblages from a "matching matrix"}

Knowing only the numbers of pairs of contiguous animals in colonies does not allow to go back to a unique assemblage of colonies over the unit ground area, because various assemblages can lead to the same final matching matrix. In order to generate any assemblage compatible with an existing matching matrix, the following procedure has been used:

Step 1: Construct the cumulative distribution function of remaining basic individuals, draw a random number uniformly distributed between 0 and 1 , deduce the class age corresponding to this number in the cumulative distribution function and pick a basic individual among remaining ones to start a new colony; then update the running matching matrix.

Step 2: Construct the conditional cumulative distribution function of remaining individuals staying above an individual of the class chosen in the previous step, draw a random number uniformly distributed between 0 and 1 , deduce the class age corresponding to this number in the conditional cumulative distribution function and pick a remaining individual in this class to put it on the top of the growing colony; then update the running matching matrix. Iterate step 2 until the conditional cumulative probability of a new additional individual vanishes to zero

Step 3: restart at step 1 if the running matching matrix is not empty.

Each colony formed is described by the sequence of the age-classes involved, starting left with the youngest (top) individual and moving right up to the oldest (basic) individual. 


\subsubsection{Computing synthetic descriptors of the colony assemblages}

One of the simplest is the distribution of colony length (or chain length). As the slipper limpet rarely reaches the age of 10 years, we assume in the model that there are $\mathrm{p}=9$ year classes in the population, which allows a simple coding of any colony (chain) by an integer between 1 and 123456789, and a straightforward identification of the length of a chain by ceiling its decimal logarithm. As the procedure for creating a colony assemblage previously described may be run many times, some statistics about global descriptors of the topological structure of the population of colonies may be easily deduced.

\subsubsection{Taking into account secondary chains}

In many cases, colonies are not linear, but exhibit one or several bifurcations, caused by multiple recruitment on an existing colony. In order to take into account this supplementary complexity of the colony topology, we have added an optional module to the slipper limpet model dealing with the possibility of forming secondary chains, limited however to one secondary chain per animal already included in a primary chain. In order to stay within the previous frame of the "matching matrix", we have used the upper-right empty triangle of this matrix to host, in a head to tail disposition, the counts of pairs of contiguous animals at the basis of the secondary chains. So, the cell $(p+2-i, p+2-j)$ gives the number of individuals of age class $i$, belonging to primary chains, on which a secondary chain beginning by an individual of age class $\mathrm{j}$ is attached. This upper-right triangular part of the "matching matrix" plays for the secondary chains the role of the row 0 for the primary chains. For primary chains, as the benthic substratum is unique and common to all basic animals, a vector (i.e. row 0 ) suffices to fully describe the distribution of basic animals into the age-classes; for secondary chains, the substratum is an animal, which may be chosen among different age-classes, so that a full description of basic animals requires a two-dimensional coding (i.e. a triangular part of a matrix). The pairs of contiguous animals in secondary chains which are not at the basis of the secondary chains are counted in the lower left triangle of the "matching matrix", along with those in primary chains. Of course, this new filling of the matching matrix induces that the vector containing the sums of the $(p+1)$ rows is no longer identical to the one containing the sums of the $(p+1)$ columns. As an example, the "matching matrix" of a population containing only one colony with a secondary chain is given in Fig.1 (right panel).

Numerical coding of secondary chains is done as in the case of primary chains, but in order to track the precise location of departure of the secondary chain, the age of the primary chain individual on which the secondary chain starts is added at the right of the number coding for the chain. To distinguish primary chain 
codes, 0 is added at their right. So, for example, coding a chain made of 3 individuals, which are respectively 4 , 2 and 1 year old, will now require a number with 4 digits: 1240 if it is a primary chain, 1246 if it is a secondary chain starting on a 6 year old animal of a primary chain. When secondary chains are allowed, the procedure of reconstructing colony assemblages from the "matching matrix" is first applied to the secondary chains, and then to the primary chains.

The probability of recruitment of a larva on an animal already embedded in a primary chain is considered as proportional to the area of the visible part of its shell. So, at the population level, the global probability of fixing a larva on a $\mathrm{i}$ years old animal is the sum of the existing free areas left by the $\mathrm{i}-1, \mathrm{i}-2, \ldots, 1$ year old animals making contiguous pairs on an a i years old animal not yet supporting a secondary chain, divided by the bottom area available for one larva. As basic animals of secondary chains grow, they can reach a size too large to be compatible with the space left between the two animals of the primary chain they are attached on. In the model, basic animals of secondary chains are randomly killed until the total coverage of basic animals goes back under the maximum area available left between the two year classes under consideration in the primary chains.

\subsubsection{Applying the colony model to non-colonial species}

For a non-colonial species (e.g. a bivalve species), a matching matrix is no more necessary and can be replaced by the conventional vector of age class abundances. But our colony model can also be run instantaneously in a non-colonial mode by simply putting to zero the probability of recruitment on existing benthic animals: the unique target of recruitment is then the remaining bare ground, with a preference coefficient $\alpha=1.0$. The probability pr of recruitment on bare ground is computed every time step following Eq. 8. If we call bivalve_usable_area the bottom area left free for bivalve recruitment by the two species, we have:

bivalve_usable_area $=$ total_bottom_area $-f_{v} x$ total_bivalve_area $-(1-6) \times$ total_slipper limpet_area

$p r=$ min[bivalve_usable_area/total_bottom_area, bivalve_usable_area/1_year_bivalve_individual_area] (Eq. 8)

$\mathrm{fv}$ is the "vital factor" of the bivalve, i.e. the ratio of the "vital area" necessary to an animal to its real ventral surface, whereas $\beta$ is the fitness coefficient for recruiting a bivalve on a bottom colonized by slipper limpets. Here the case of a particular bivalve (the scallop Pecten maximus) has been tested, because of its economical weight in the French seafood industry, and because it is hampered by the lack of space in dense slipper limpet beds, as well as by the slipper limpet stacks which live attached on its shell. Dupouy and Latrouite (1979) 
mentioned than in 1977, 10\% of the scallops of the bay of Saint-Brieuc (Western English Channel) carried chains of slipper limpets, with a mean of 5 individuals per scallop. Guérin (2004) found in the bay of Brest a mean of 5 stacks (corresponding to a total of 15 animals) per scallop, but found some old scallops carrying up to 100 slipper limpets forming up to 20 stacks. The interaction between slipper limpets and scallops can be easily simulated by adding to the slipper limpet "matching matrix": 1/ the scallop population vector as a supplementary row; 2/ another supplementary row per scallop year class to keep track of the year classes of the slipper limpets which build the basis of chains attached on this scallop year class. As in the case of secondary chains in the slipper limpet colonies, the basic individuals of stacks cannot be older than the scallop hosting the stack; so, these supplementary rows will not be fully used, only a triangular part will be fulfilled. As for the slipper limpet, the model uses for the scallop a von Bertalanffy growth curve for the diameter L of the shell (Antoine, 1979) but uses an hyperbolic size-dependence of the fecundity $e_{2} /\left(e_{3}+L\right)$ adjusted to the data of Paulet and Fifas (1989); parameter values are given in Table 1.

\subsection{Field data}

Our laboratory has sampled, at two times (2002 and 2012), the French site being the most heavily occupied by the slipper limpet, i.e the so-called Golfe Normano-Breton, on the French side of the English Channel. In every sample, we have measured the abundance of every year class (individual age is deduced from the number of growth rings on the shell), the age sequence in every primary or secondary chain, the size and sex of every animal.

In 2002, 5 stations (Fig. 2) have been sampled with a Hamon grab (area $=0.25 \mathrm{~m}^{2}$ ) and revealed various levels of colonization by the slipper limpet. Located between Jersey island and the Cotentin peninsula, the stations 197 (363 ind./0:25 $\left.\mathrm{m}^{2}\right), 210\left(388 \mathrm{ind} . / 0: 25 \mathrm{~m}^{2}\right)$ are heavily occupied, whereas station $209(39$ ind./0:25m²) is weakly populated. The two stations $97\left(144\right.$ ind./0:25 $\left.\mathrm{m}^{2}\right)$ and $58\left(100\right.$ ind./0:25 $\left.\mathrm{m}^{2}\right)$ located in the bay of SaintBrieuc exhibit a medium occupation. In 2012, 2 stations have been sampled by divers $\left(\operatorname{area}=1.25 \mathrm{~m}^{2}\right.$ each) in the bay of Saint-Brieuc, the first PP1 in a recently invaded zone $\left(1600\right.$ ind. $\left./ \mathrm{m}^{2}\right)$, the second PP2 in a more anciently and heavily colonized region $\left(2500 \mathrm{ind} . / \mathrm{m}^{2}\right)$. 


\section{Results}

\subsection{Dynamics of the slipper limpet population alone}

Running the simplest version of the slipper limpet model (i.e. without secondary chain formation), with a constant annual larval input, first reveals that, whatever the colonial structure of the initial population, the system converges in less than 30 years towards a unique structure of the colonial population, corresponding to a unique "matching matrix". In case of a constant larval input of $3.10^{6}$ larvae per year, a dilution factor equal to 10 and a survival rate at the end of pelagic phase set to 0.02 (i.e. 6000 larvae successfully recruited per $\mathrm{m}^{2}$ per year), Figure 3 shows the time-course of the bottom coverage for three different initial distributions of animals in the system: only 200 9-years old individuals, only 200 1-year old individuals, or 1 single colony containing one animal of each class. Figure 3 gives also one distribution of the colony length reconstructed from the values of the steady state "matching matrix" given beside. The steady state bottom coverage obtained under various forced inputs of larvae (Fig. 4) shows that a permanent and significant benthic population can settle only if the annual larval input is sufficient. The response of the bottom coverage of the final steady state population to the larval input is S-shaped, with an inflexion point when the number of larvae reaching the bottom is between 300 and 350 larvae. $\mathrm{m}^{-2} \cdot \mathrm{y}^{-1}$. Then, the model can be run in a slightly more realistic way, i.e. fed by its own larval production, spawn by the current different age-classes, instead of being forced by a constant, external larval input. As larvae are emitted in the water flowing over the benthic area, a part of them will be lost by dilution. The number of larvae settling really on the study area is then equal to the number of emitted eggs divided by the dilution factor. When dilution is too strong (>90), the population does not succeed to settle. In case of weak or moderate dilution, the population converges towards the same stable steady state, covering totally the substrate. Only the time necessary to reach this stable steady state does change, from 10 years when no dilution occurs, to 90 years at maximum dilution, i.e. 90 . So, in both cases of larval input (i.e. maintained constant every year or computed from the local production of existing adults), the population's attractor can be considered as robustly stable. As the model solves the overcrowding problem by random killing of basic individuals, and uses different random numbers at each run of the model, the spawning population changes every year, and so does the number of larvae settling annually in the case of internal supply of larvae by the population: the random treatment of the competition for space blurs the final "matching matrix". In that case, the global incertitude around the histogram of steady state chain length results from the addition of the variability induced by the random reconstruction of chains from every "matching matrix" to the variability created by the random treatment of bottom coverage overshooting. Figure 5 shows the result of 50 runs, each with 50 reconstructions of chain sets, on the left in the 
case of imposed moderate larval input and on the right in the case of an annual larval input linked to the adult density. This figure shows also that increasing steady state coverage causes a shift of the modal length of chains from 2 to 4 individuals.

Allowing the creation of secondary chains does not alter significantly the steady state bottom coverage nor the structure of the primary chains, whose modal length locks again at 4 animals, whatever the larval input. The histograms of primary chain lengths obtained with larvae locally produced by the existing adults (Fig. 5 right and Fig. 6 up right) compare reasonably to histograms of primary chain lengths observed at different places and years by our lab (Fig.7 top panel) in the bay of Saint-Brieuc (western English Channel). The histogram of secondary chain lengths exhibits a shape quite different from the histogram of primary chains: due to the lack of space between two adjacent animals in a primary chain, the histogram is drastically skewed towards short lengths, looking as an exponential distribution, as also observed in the bay of Saint-Brieuc (Fig.7 bottom panel). Allowing secondary chains increases the total animal abundance by $30 \%$.

\subsection{Dynamics of the scallop population}

When applied to the scallop alone, our model reduces to a simple p year class model with space competition between individuals. As scallops never occupy the total available ground area, and because observed maximum abundances of exploitable scallops (age $\geq 3$ years) are between 1 and 2 ind. $\mathrm{m}^{-2}$ in very favorable spots preserved from slipper limpet colonization, we attributed to the scallop a "vital factor" fv set to 50 .

Competition for space leads to abundance oscillations: after a transitory phase, the population reaches a limit-cycle. The main period of this cycle revealed to be nearly insensitive to the maximum individual size or to the mortality rate of the species, but mainly conditioned by the speed of growth of the species : the more quickly it reaches its maximum adult size, the shorter is the period and the weaker are the successive harmonics of the fundamental oscillation. With an actual von Bertalanffy $\mathrm{K}$ parameter equal to $0.545 \mathrm{y}^{-1}$, the scallop exhibits a simulated period between 10 and 12 years. The same simulation considering a bivalve having a very slow growth $\left(\mathrm{K}=0.1 \mathrm{y}^{-1}\right)$ gives a 15 years period, whereas for a bivalve having a very fast growth $\left(\mathrm{K}^{-1.5} \mathrm{y}^{-1} 1\right)$, the period would fall to 6 years (Fig. 8). Increasing the vital area does not change the main period, but spreads the spectrum over more frequencies (compare $f v=1$ to $f v=50$ in Fig. 8), so that the limit cycle is more and more blurred by noisy fluctuations. 


\subsection{Competition between the slipper limpet and the scallop}

Running the coupled model requires setting a probability for scallops to recruit and survive on existing beds of slipper limpets. As benthic scallops are capable of some displacement near the sea bottom by ejecting water from their bivalve inner volume, adult individuals are currently observed resting on dense slipper limpet beds, even if their abundance is diminished relatively to slipper limpet-free areas. As for slipper limpet recruitment on bare grounds, we have adopted a simple fitness coefficient $\beta$ for recruiting scallop on a bottom colonized by slipper limpets: $\beta=0$ prevents from any scallop recruitment (i.e. total exclusion of scallops from slipper limpet beds), whereas $\beta=1$ abolishes the competition for space caused by the slipper limpet population. Decreasing $\beta$ lowers the scallop mean abundance in the steady state (Fig. 9), and damps its limit cycle: moving from $\beta=1.0$ to $\beta=0.8$ increases the period from 10 to 13 years, whereas moving to $\beta=0.6$ turns the limit cycle into a damped oscillation leading to a constant steady state.

\section{Discussion}

The success of colonization by a benthic species is obviously very sensitive to the survival rate from egg to benthic recruit, which is very difficult to assess in the field. When they are four year old, scallops can spawn about $10^{7}$ eggs, whereas slipper limpets breed only $10^{4}$ small larvae (Deslous-Paoli and Heral, 1986), after incubation of the first stages of embryonic development in egg capsules. For the Georges Bank scallop Placopecten magellanicus, McGarvey (1991) gives a survival rate value of 0.014 from the egg to the pelagic larva, and only 0.00002 from larva to 2 year old benthic animal, which gives a global survival rate of $3.10^{-7}$ from egg to benthic young animal, which is ten times the value we have imposed (dilution factor=30 and larval survival rate $=10^{-6}$ ) to obtain a density of fishable scallops (age $\geq 3$ years) not exceeding 1.5 ind. $\mathrm{m}^{-2}$. For the slipper limpet, the survival rate from egg to young recruit should be in the inverse ratio of the broods, i.e. around $10^{-3}$. Apart from the survival rate, the dilution factor also is a very sensitive parameter: no dilution induces a quick colonization of the total available area, and hence a strong density dependence, whereas too much dilution prevents both species from settling. The mean value (38) numerically found for the dilution factor on the Bay of Biscay-English Channel continental shelf (see part II of this paper) by starting with an equal number of larvae released in all the meshes of a hydrodynamical model of the region, computing their drift during 20 days, and finally summing in each mesh the larvae coming from all the meshes, is similar to the value (30) used in our standard simulations, and within the range here tested for the sensitivity to the dilution factor (0 to 100). 
When a healthy larva settles on the ground, its final benthic place will depend on its capability of partially correct its initial drop place, for instance by creeping towards a preferred target. Larvae of slipper limpets are known to require solid substrates, and to be attracted by existing living colonies of adults (Cahill and Koury, 2016). Pecten maximus pediveligers seem not to be attracted by chemical stimuli coming from benthic adults, but require clean silt-free surfaces and not too turbulent conditions at the sediment-water interface (Le Pennec et al., 2003). As the precise mechanisms have not yet been mathematically formulated, we have adopted a simple probabilistic approach in this first model, linking the probability of settling on three types of substrates (bare ground, slipper limpet bed, scallop shells) to their relative part in the bottom area, weighted by a preference coefficient between 0.0 and 1.0. For the slipper limpet, the value of $\alpha$ has been calibrated to obtain a complete benthic coverage after 20 to 30 years when starting from a few animals, as observed in the bay of Brest during the second half of the $20^{\text {th }}$ century; the low value of $\alpha$ is in favor of a greater attractiveness of benthic alive animals on slipper limpet larvae. Interestingly, in the case of slipper limpets, using the strict specific dorsal area of each age-class of top animals as the basis of their "attractiveness" induced ample limit cycles, which seem not to appear in real environments, along with distributions of the length of slipper limpet chains systematically skewed in favor of short chains. Giving to every benthic slipper limpet the attractiveness of the total population coverage, instead of its specific year-class ground coverage, turned the population steady state into a stable attractor, and improved drastically the shape of the simulated distribution of the length of slipper limpet chains, with a clear mode at 4 individuals, and very few short chains, as observed in the field.

For benthic adults, the natural mortality rate observed for animals aged less than 6 years is about $0.16 \mathrm{y}^{-1}$ (Coum , 1979; Deslous-Paoli, 1985) for the slipper limpet and between 0.1 and $0.15 \mathrm{y}^{-1}$ (Rees and Dare, 1993) for the king scallop. In areas of heavy fishing activity, the real mortality rate may be ten times higher for scallops (McGarvey, 1991), so that the population in these places lacks old and big individuals, having the highest fecundity. As fishers throw out again the dredged slipper limpets, scallop fishery induces an additional mortality on these slipper limpets, which remains unknown. In this model focused on the expansion of the two species in absence of fishing, we have used natural mortality rates near their low field estimates $\left(\mathrm{m}=0.15 \mathrm{y}^{-1}\right.$ for slipper limpet and $\mathrm{m}=0.1 \mathrm{y}^{-1}$ for scallop).

The strong oscillation which affects the simulated abundance of scallop is compatible with the observed fluctuations of the French scallop fishery landings (Fig. 10): in the bay of Saint-Brieuc (Lesueur et al., 2009), the strongest oscillation has a mean period of 10.5 years (maxima observed in 1973, 1986, 1995 and 2005) but in the bay of Brest, where the speed of growth is higher (Thouzeau et al., 2000), the main period observed before the 
collapse of the fishery has been as low as 5 years (maxima observed in 1953, 1959, 1963). Same oscillations seem also to have been reported for other exploited Pectinidae (Fig. 10). Placopecten magellanicus has a mean period of 9 years (maxima observed in 1927, 1936, 1945, 1953 and 1964) in the North-American bay of Fundy (Caddy, 1979), or between 8 and 11 years (peaks observed in 1953, 1961, 1972, 198, 1991 and 2000) along the Maine coast (Kelly, 2014) before the 2005 collapse. Euvola ziczac of the Brazilian coast (Pezzuto and Borzone, 2004) has a main period of 5 years (maxima observed in 1975, 1980, 1985). Argopecten ventricosus in Mexico (Felix-Pico et al.., 2007) has a main period about 7 years (maxima observed in 1989, 1996, 2002). Table 2 summarizes the values found in the literature for these 4 species concerning the oscillation period as well as the von Bertalanffy K parameter of growth. This cycling behavior has been attributed to three main different causes. Dickie (1955), Sutcliffe et al. (1977), Caddy (1979), Drinkwater (1987) and Cabilio et al. (1987) linked the oscillation of period between 4 and 5 years and it harmonics appearing in the landings of Bay of Fundy scallop (Placopecten magellanicus) to a forcing by an external, natural variable, i.e. the lunar nodal tidal fundamental period of 18.6 years. Remarking that no clear phase relationship arises between the 18.6 year temperature variation and landings of different species from the same area, including scallop, McGarvey (1991) invoked another cause for explaining observed cycles in the Bay of Fundy harvested scallop population: a predator-prey oscillation between the species and the human fishing effort. But a third cause can also be invoked: the densitydependence internal feed-back of populations mainly based on trophic aspects (food availability, cannibalism of the old animals upon their juveniles, disturbance caused by accumulated fecal matter...) or on competition for space leading to active repulsion between individuals of the same species. Ricker (1954) stated that the period of oscillation induced by the density dependence in multi-age spawning populations should be twice the mean age of maturity, whatever the exact shape of the reproduction curve and of the number of generations in the spawning stock. With a main oscillation period about 5 times its age of first maturity, the scallop does not seem to follow this statement. Ricker also found that introducing fishing mortality on old year classes induces a decline in the average age at maturity and in the period of oscillations, as well as a dramatic decrease of their amplitude, leading to a virtual steady state above a certain level of exploitation. So, almost no previous work mentioned the competition for space as a possible cause of natural oscillations in bivalve abundance. This paper suggests that this competition could generate strong oscillations expressing a fundamental mode of this kind of biological systems. 


\section{Conclusion}

The ordered grouping of animals of different age classes in stacks is a specific trait of the gastropod Crepidula fornicata which has not been modelled so far, although it may explain part of the obvious capacity of that species to invade and totally occupy various marine bottoms. An incomplete, but tractable way to model the building and decay of these stacks has been proposed using a so-called "matching matrix", which describes only the distribution of the pairs of adjacent animals. This technique allows the reconstruction of sets of stacks (chains) by random allocation of animals in accordance to the remaining pairs in the progressively exhausted matching matrix. It allows also recording the various departures of secondary chains on animals already embedded in a primary chain. Moreover, adding supplementary rows to this matrix allows to record also the departures of chains stuck on some bivalves used as phoretic vectors. Here we have chosen the scallop Pecten maximus because of its economic value and the strong diminution of its population caused by the competition for space with the slipper limpet. The two species population models used separately show stable attractors: a pure constant steady state for the slipper limpet, a limit cycle or a constant steady state for the scallop, depending on the recruitment success of the pelagic larvae. The 11 years period found for the scallop has been retrieved in the landings of the French fishery of the bay of Saint-Brieuc. The steady state of the slipper limpet corresponds to a particular unimodal distribution of stack lengths, which has a mode at 4 individuals, like in the field. Running both models together shows that a simple $40 \%$ unsuitability of slipper limpet beds to scallop recruitment leads to a $50 \%$ loss of scallop, and the disappearance of its limit cycle. Such a quantitative description of phoresis and competition for space should be helpful in modelling habitat colonization and structuring by sessile invertebrates.

\section{Acknowledgements}

This modelling approach has been possible thanks to the 20 year long expertise gained by our LEBCO lab in the description and mapping of the slipper limpet invasion along the French coasts. We would like to thank especially our retired colleagues Michel Blanchard and Dominique Hamon, and our present colleague Antoine Carlier, who have furnished field data, and Jean-Dominique Gaffet and Xavier Caisey, who helped collecting and treating the data at sea and in the lab. The work by Thomas Grégoris has been done during a INSA Lyon training course granted by Ifremer. 


\section{References}

Antoine L., 1979. La croissance de la coquille Saint-Jacques Pecten maximus et ses variations en Mer Celtique et en Manche. PhD thesis, Université de Bretagne occidentale, 148 p.

Blanchard M., 1995. Origine et état de la population de Crepidula fornicata (Gastropoda, Prosobranchia) sur le littoral français. Haliotis, 24: 75-86.

Blanchard M., 1996. Spread of the slipper limpet Crepidula fornicata (L.) 1758 in Europe. Current state and consequences. Scientia Marina 61, 109-118.

Blanchard M., Blanchet A., Gaffet J.-D., Hamon D., 2001.Dynamique de population de la crépidule (Crepidula fornicata) en baie de Saint-Brieuc (Manche-Ouest). Rapport Ifremer RST.DEL/00.08/Brest, 60 p. + annexes.

Bohn, K., Richardson, C.A., Jenkins, S.R., 2012. The invasive gastropod Crepidula fornicata: reproduction and recruitment in the intertidal at its northern most range in Wales, UK, and implications for its secondary spread. Mar. Biol. 159, 2091-2103.

Bohn, K., Richardson, C.A., Jenkins, S.R., 2013. Larval microhabitat associations of the non-native gastropod Crepidula fornicata and effects on recruitment success in the intertidal zone. J. Exp. Mar. Biol. Ecol., 448: 289-297.

Cabilio, P., Dewolfe D.L., Daborn G.R., 1987. Fish catches and long-term tidal cycles in Northwest Atlantic Fisheries: a nonlinear regression approach. Can. J. Fish. Aquat. Sci. 44: 1890-1897.

Caddy J.F., 1979. Long-term trends and evidence for production cycles in the Bay of Fundy scallop fishery, Rapports et Procès-verbaux de la Réunion du Conseil International pour l’Exploration de la Mer, 175, 97-168. Cahill AE. 2015. Adult density affects larval recruitment in the calyptraeid gastropod Crepidula fornicata. Journal of Experimental Marine Biology and Ecology, 465:77-82

Cahill, A. E., Koury, S. A., 2016. Larval settlement and metamorphosis in a marine gastropod in response to multiple conspecific cues. PeerJ, 4, e2295. http://doi.org/10.7717/peerj.2295

Chauvaud L, Patry Y, Jolivet A, Cam E, Le Goff C, Strand Ø., Charrier G, Thébault J. , Lazure P. , Gotthard K., Clavier J., 2012. Variation in size and growth of the Great Scallop Pecten maximus along a latitudinal gradient. PLoS ONE 7(5): e37717. doi:10.1371/journal.pone.0037717

Coum A., 1979. La population de crépidules Crepidula fonicata (L.) en rade de Brest : écologie et dynamique.

Thèse de doctorat, Université de Bretagne Occidentale, Brest, France, 134 pp.

Deslous-Paoli J.M., 1985 - Crepidula fornicata L. (gastéropode) dans le bassin de Marennes-Oléron ; structure, dynamique et production d'une population. Oceanologica Acta 8 (4) : 453-460. 
Deslous-Paoli J.M., Héral M., 1986. Crepidula fornicata L. (Gastéropode, Calyptraeidae) dans le bassin de Marennes-Oléron : composition et valeur énergétique des individus et des pontes. Oceanol. Acta, 9, 305-311.

Dickie, L.M. 1955. Fluctuations in abundance of the giant scallop, Placopecten maaellanicus (Gmelin), in the Digby area of the Bay of Fundy. J. Fish. Res. Board Can. 12: 797-857.

Drinkwater K.F. 1987. "Sutcliffe revisited": previously published correlations between fish stocks and environmental indices and their recent performance, p. 41-61. In R.I. Perry and K.T. Frank [ed.] Environmental effects on recruitment to Canadian Atlantic fish stocks. Can. Tech. Rep. Fish. Aquat. Sci. 1556.

Dupouy H., Latrouite D., 1979. Le développement de la crépidulc sur le gisement de coquilles S'I: Jacques de la baie de Saint-I3rieuc. Science et Pêche 292: 13-19.

Ehrhold A., Blanchard M., Auffret J.P., Garlan T., 1998. Conséquences de la prolifération de la crépidule (Crepidula fornicata) sur l'évolution sédimentaire de la baie du Mont Saint-Michel (Manche, France). C.R. Acad. Sci., Paris 327, 583587.

Félix Pico, E.F., Arellano-Martínez M., Ramírez-Rodríguez M., López-Rocha J., 2007. Some recent trends in Magdalena Bay Pacific Calico scallop populations. In: 16th International Pectinid Workshop (11 - 18 May, 2007, Halifax, Nova Scotia, Canada). 50-51.

Fretter, V., Graham, A., 1981. The Prosobranch Molluscs of Britain and Denmark. Part 6. Journal of Molluscan Studies, Supplement 9, 309-313.

Guérin L., 2004. La crépidule en rade de Brest: Un modèle biologique d'espèce introduite proliférante en réponse aux fluctuations de l'environnement. Thèse de doctorat de l'Université de Bretagne Occidentale, Brest. $323 \mathrm{p}$.

Hamon D., Blanchard M., 1994. Etat de la prolifération de la crépidule (Crepidula fornicata) en baie de SaintBrieuc. Rapport Ifremer-DEL 94.14, 29 p. + annexes.

Hamon, D., M. Blanchard, E. Houlgatte, A. Blanchet, J.D. Gaffet, P. Cugier, A. Ménesguen, P. Bassoulet, P. Cann, D. Domalain, and A.G. Haubois. 2002. "La crépidule: identifier les mécanismes de sa prolifération et caractériser ses effets sur le milieu pour envisager sa gestion. Chantier Baie de Saint-Brieuc.” Rapport Final Programme LITEAU 1ère Tranche, Ifremer DEL, Brest, France.

Harris B. P, Stokesbury K. D. E., 2006. Shell growth of sea scallops (Placopecten magellanicus) in the southern and northern Great South Channel, USA, ICES Journal of Marine Science, 63, 811-821.

Hart D.R., Chute A.S., 2009. Estimating von Bertalanffy growth parameters from growth increment data using a linear mixed-effects model with an application to the sea scallop Placopecten magellanicus. ICES J. Mar. Sci., 66, 2165-2175. 
Hernandez-Lllamas A., Ratkowsky D.A., 2004. Growth of fishes, crustaceans and molluscs: estimation of the von Bertalanffy, Logistic, Gompertz and Richards curves and a new growth model. Mar Ecol Prog Ser $282: 237-244$

Kelly, K.H., 2014. Results from the Spring 2013 Maine sea scallop survey. Maine Department of Marine Resources, Research Reference Document, 47 p.

Le Pennec M., Paugam A., Le Pennec G., 2003. The pelagic life of the pectinid Pecten maximus - a review. ICES J. Mar. Sci., 60 (2): 211-233.

Lesueur M., Roncin N., Le Gallic B., Ropars-Collet C., 2009. La pêche de la coquille Saint-Jacques en baie de Saint-Brieuc: description de la pêcherie et des systèmes de gestion et de contrôle. Publication AMURE, Série Rapport, $\mathrm{N}^{\circ} 15,35$ p. http://halieutique.agrocampus-ouest.fr/pdf/8.pdf.

Lindenmayer A., 1968. Mathematical models for cellular interaction in development. J. Theoret. Biol., 18, 280315.

McGarvey R., 1991. Dynamics of the Georges Bank scallop fishery. PhD thesis, Dalhousie University,260 p.

Marteil L, 1963. - La crépidule en France. - Science et Pêche, Bull. Inst. Pêches Marit., 121: 1-6.

Marteil L., 1965. Extension de l'aire géographique de Crepidula fornicata (L) pendant l'année 1964. Sciences et Pêches, 135: 5-6.

Parrish J.K., Edelstein-Keshet L., 1999. Complexity, pattern, and evolutionary trade-offs in animal aggregation. Science, 284 (5411), 99-101.

Paulet, Y.M., Fifas, S., 1989. Etude de la fécondité potentielle de la coquille St-Jacques en Baie de St-Brieuc. Haliotis, 19, 275-285.

Pezzuto P.R., Borzone C.A., 2004. The collapse of the scallop Euvola ziczaz (Linnaeus, 1758) (Bivalvia: Pectinidae) fishery in Brazil: Changes in distribution and relative abundance after 23 years of exploitation. Brazilian Journal of Oceanography 52, 225-236.

Rees, H.L., Dare, P.J., 1993. Sources of mortality and associated life-cycle traits of selected benthic species: a review. Fisheries Research Data Report No 33. Directorate of Fisheries Research, Lowestoft, 36pp.

Richard J., Huet M., Thouzeau G., Paulet Y.-M., 2006. Reproduction of the invasive slipper limpet, Crepidula fornicata, in the bay of Brest, France. Mar Biol 149:789-801

Ricker W.E., 1954. Stock and recruitment. J. Fish. Res. Board Can. 11: 559-623. 
Sauriau, P.G., Pichocki-Seyfried, C., Walker, P., De Montaudouin, X., Palud, C., He'ral, M., 1998. Crepidula fornicata L. (mollusque, gastéropode) en baie de Marennes-Oléron: cartographie des fonds par sonar à balayage latéral et estimation du stock. Oceanol. Acta 21, 353 - 362.

Sutcliffe, W.H., Jr., Drinkwater K., Muir B.S., 1977. Correlations of fish catch and environmental factors in the Gulf of Maine. J. Fish. Res. Board Can. 34: 19-30.

Thouzeau G, Chauvaud L, Grall J, Guérin L, 2000. Rôle des interactions biotiques sur le devenir du prérecrutement et la croissance de Pecten maximus (L.) en rade de Brest. C R Acad Sci Paris Sci Vie, 323:815-825. 


\section{Table captions}

Table 1. Parameters used in the OD model of slipper limpet and scallop populations.

Table 2. Period (years) of the abundance oscillation and von Bertalanffy K parameter of growth of four exploited species of Pectinidae. 


\begin{tabular}{|c|c|c|c|c|}
\hline Parameter & Description & Unit & $\begin{array}{l}\text { Value for } \\
\text { slipper limpet }\end{array}$ & $\begin{array}{l}\text { Value for } \\
\text { scallop }\end{array}$ \\
\hline $\mathrm{m}$ & Natural mortality rate of adults & $\mathrm{y}^{-1}$ & 0.1 & 0.15 \\
\hline a & Probability of rearrangement of broken chains & $\mathrm{y}^{-1}$ & 0.3 & - \\
\hline $\mathrm{b}$ & Probability of of anthropogenic chain break & $\mathrm{y}^{-1}$ & 0.0 & - \\
\hline$\alpha$ & Relative affinity for bare grounds & unitless & 0.01 & 1.0 \\
\hline$\beta$ & Relative affinity for slipper limpet beds & unitless & 1.0 & 0.6 \\
\hline S & $\begin{array}{l}\text { Probability of pelagic larva survival at the end of } \\
\text { pelagic life }\end{array}$ & $\mathrm{y}^{-1}$ & 0.02 & 0.000001 \\
\hline $\mathrm{d}$ & Dilution factor of spat & $\mathrm{y}^{-1}$ & 30 & 30 \\
\hline $\mathrm{K}$ & stiffness of the von Bertalanffy growth curve & $y^{-1}$ & 0.25 & 0.545 \\
\hline $\mathrm{L}_{\infty}$ & $\begin{array}{l}\text { Asymptotic maximum length of the von } \\
\text { Bertalanffy growth curve }\end{array}$ & $\mathrm{cm}$ & 10 & 12.4 \\
\hline $\mathrm{e}_{0,} \mathrm{e}_{1}$ & $\begin{array}{l}\text { Maximum number of eggs laid by a female of } \\
1 \mathrm{~cm} \text { length and coefficient of the length in the } \\
\text { power exponent of the fecundity allometry } e_{0} \cdot L^{\mathrm{e}}\end{array}$ & eggs.ind ${ }^{-1}, \mathrm{~cm}^{-1}$ & $6,3.99$ & \\
\hline$e_{2}, e_{3}$ & $\begin{array}{l}\text { Coefficients of the hyperbolic size-dependence } \\
\text { of the fecundity } e_{2} /\left(e_{3}+L\right)\end{array}$ & eggs.ind ${ }^{-1}, \mathrm{~cm}^{-1}$ & & $117,14.6$ \\
\hline
\end{tabular}

Table 1 


\begin{tabular}{|c|c|c|c|}
\hline Species name & von Bertalanffy K & Period & Reference \\
\hline Pecten maximus & $\begin{array}{l}0.54 \text { (bay of Saint-Brieuc) } \\
0.83 \text { (bay of Brest) } \\
0.2<\mathrm{K}>0.87\end{array}$ & $\begin{array}{l}10.5 \\
5\end{array}$ & $\begin{array}{l}\text { Antoine, } 1979 \\
\text { Thouzeau et al. (2000) } \\
\text { Chauvaud et al., } 2012\end{array}$ \\
\hline Placopecten magellanicus & $0.27<\mathrm{K}<0.51$ & 9 & $\begin{array}{l}\text { Harris B. P. and } \\
\text { Stokesbury K. D. E. } \\
\text { (2006), Hart and Chute } \\
(2009)\end{array}$ \\
\hline Euvola ziczac & $?$ & 5 & $\begin{array}{l}\text { (Pezzuto and Borzone, } \\
\text { 2004) }\end{array}$ \\
\hline Argopecten ventricosus & 0.37 & 7 & $\begin{array}{l}\text { Hernandez-Lllamas A, } \\
\text { Ratkowsky DA (2004) }\end{array}$ \\
\hline
\end{tabular}

Table 2 


\section{Figure captions}

Figure 1. Examples of the "matching matrix" of a population containing only one colony without (on the left) or with a secondary chain (on the right).

Figure 2. Location of the slipper limpet samples

Figure 3. Example of results obtained by 3 runs of 50 years starting with 3 different initial populations (left panel) and converging towards a unique "matching matrix" (right top panel), leading to a certain type of chain length distribution (right bottom panel).

Figure 4. Effect of the level of constant annual larval input (expressed as number of larvae reaching the bottom per $\mathrm{m}^{2}$ per year) on the final steady state bottom coverage by the slipper limpet population.

Figure 5. Primary chain length distribution when secondary chains are not allowed, in case of imposed constant larval input (left panel) or in the case of local self-production of larvae (right panel) at steady state.

Figure 6. Primary (upper panel) and secondary (lower panel) chain length distributions in case of imposed constant larval input (left panel) or in the case of local self-production of larvae (right panel) at steady state.

Figure 7. Observed distribution of primary chain lengths (top panel) and of secondary chain lengths in the western English Channel (bay of Saint-Brieuc and Normand-Breton gulf). Data by courtesy from M. Blanchard (1998 and 2002) and A. Carlier (2012).

Figure 8. Spectrum of frequencies of 256 year long time-series of simulated bivalve abundance for 4 values of the stiffness of the age dependency of the vital surface (von Bertalanffy K parameter) and 2 values of the living space required by the bivalve (fvital parameter).

Figure 9. Time course of scallop total abundance during colonization for 3 different affinities ( $\beta$ ) of scallops for slipper limpet beds ( $\beta=1.0$ refers to the "no competition" reference, $\beta=0.6$ to a moderate competition).

Figure 10. Observed fluctuations of annual landings in some fisheries of pectinids (data have been normalized by division by the mean over the record period). Sources of data are given in the text. 
Figures

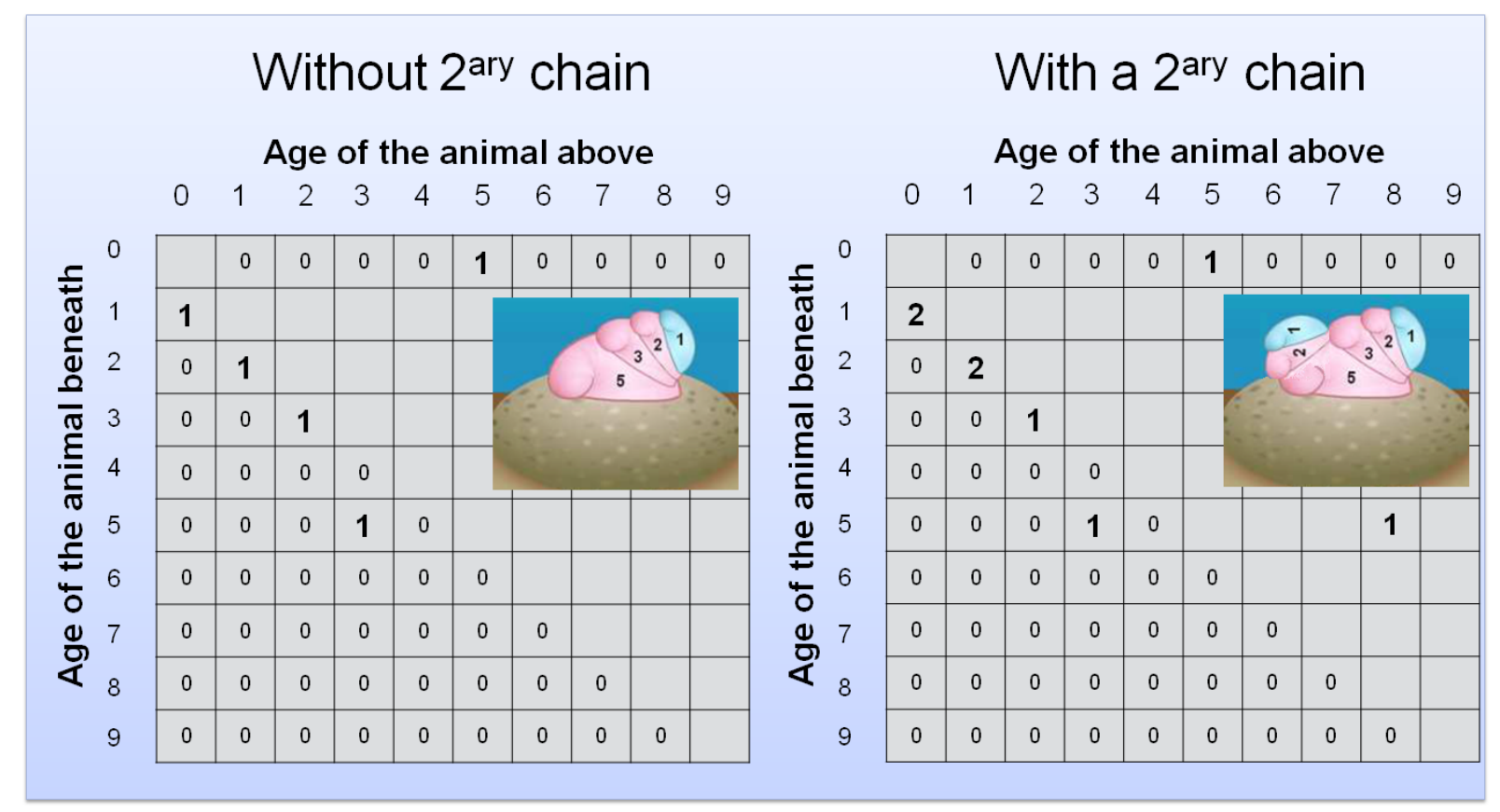

Figure 1 


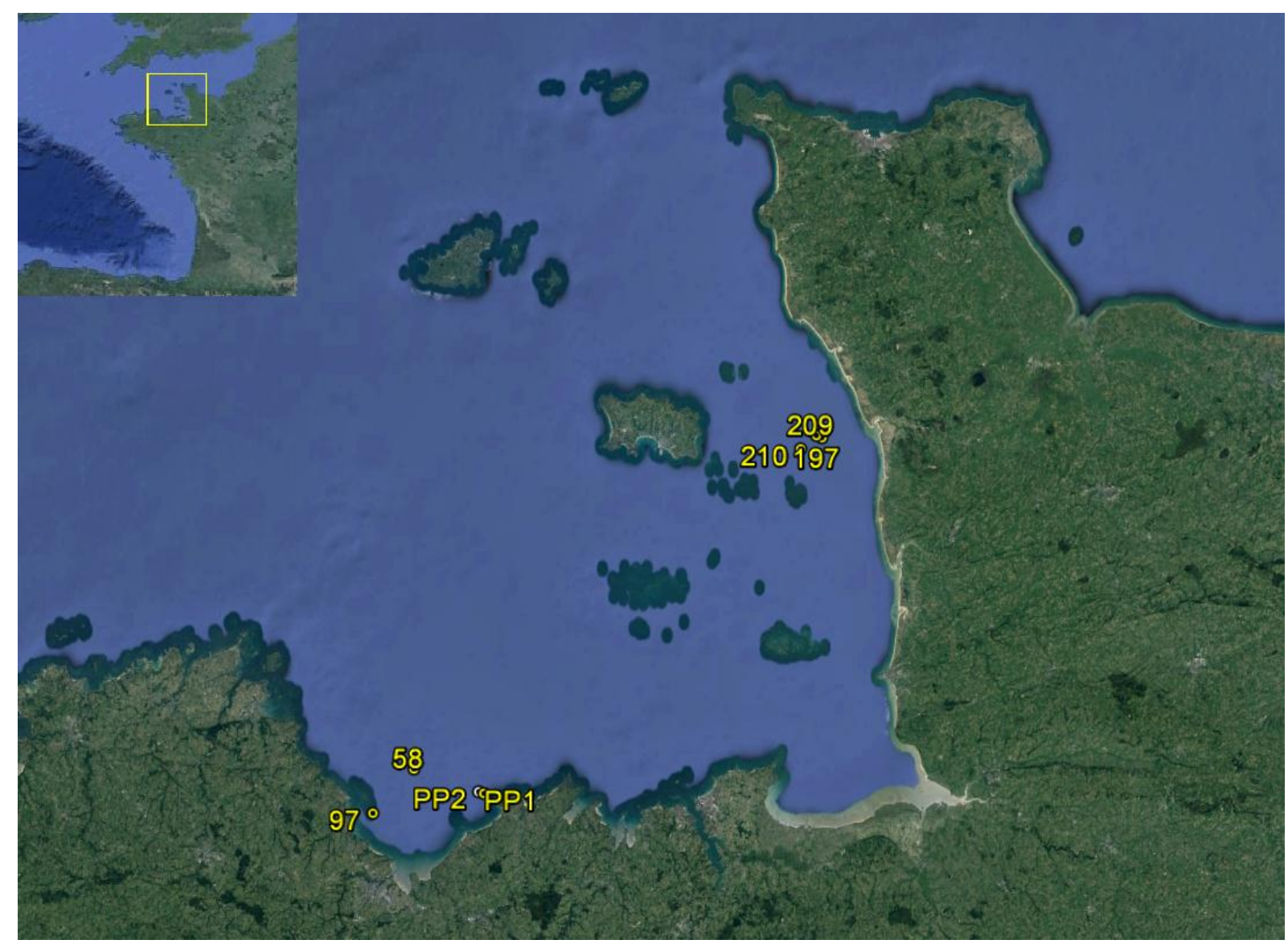

Figure 2 


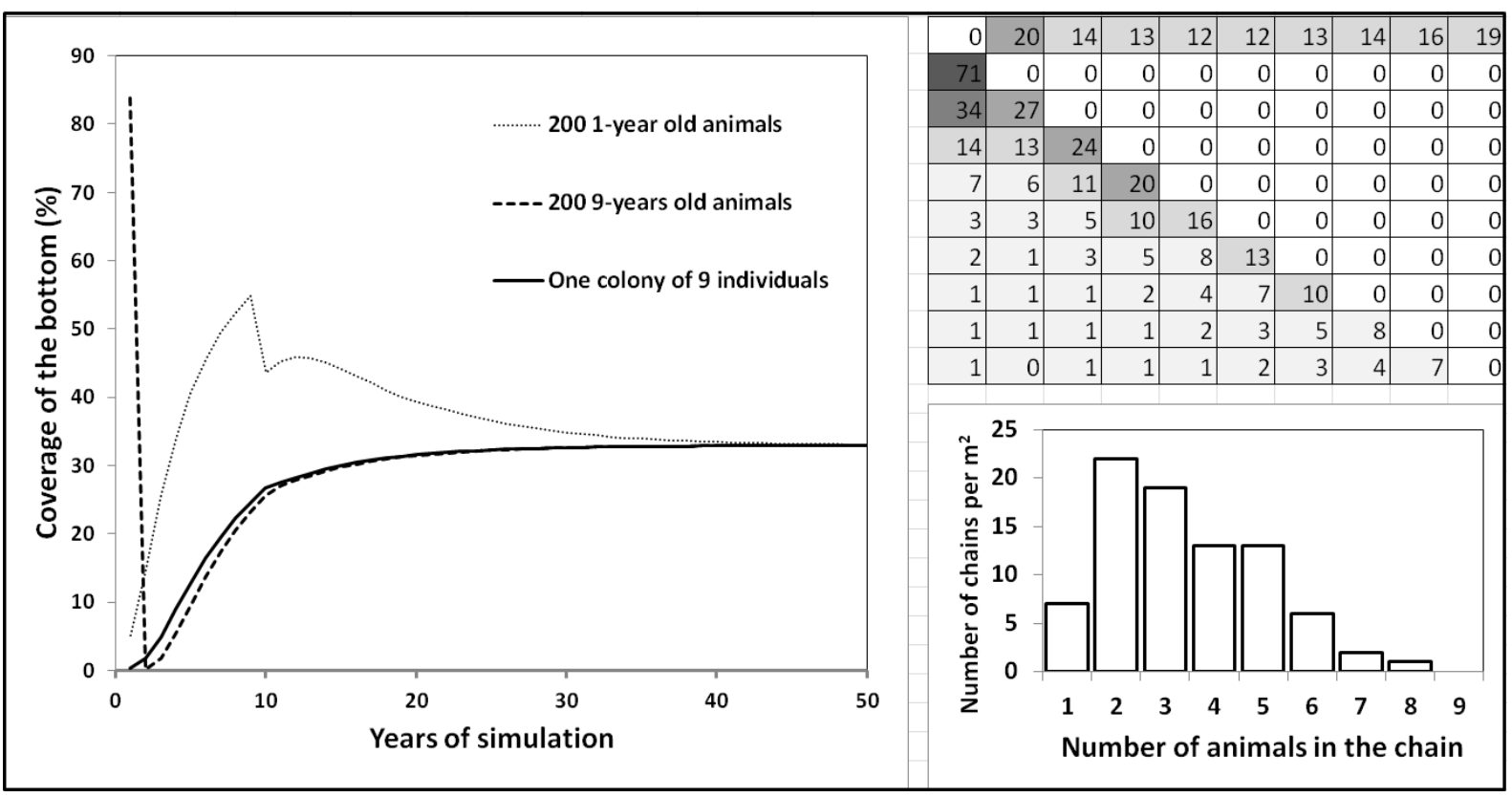

Figure 3 


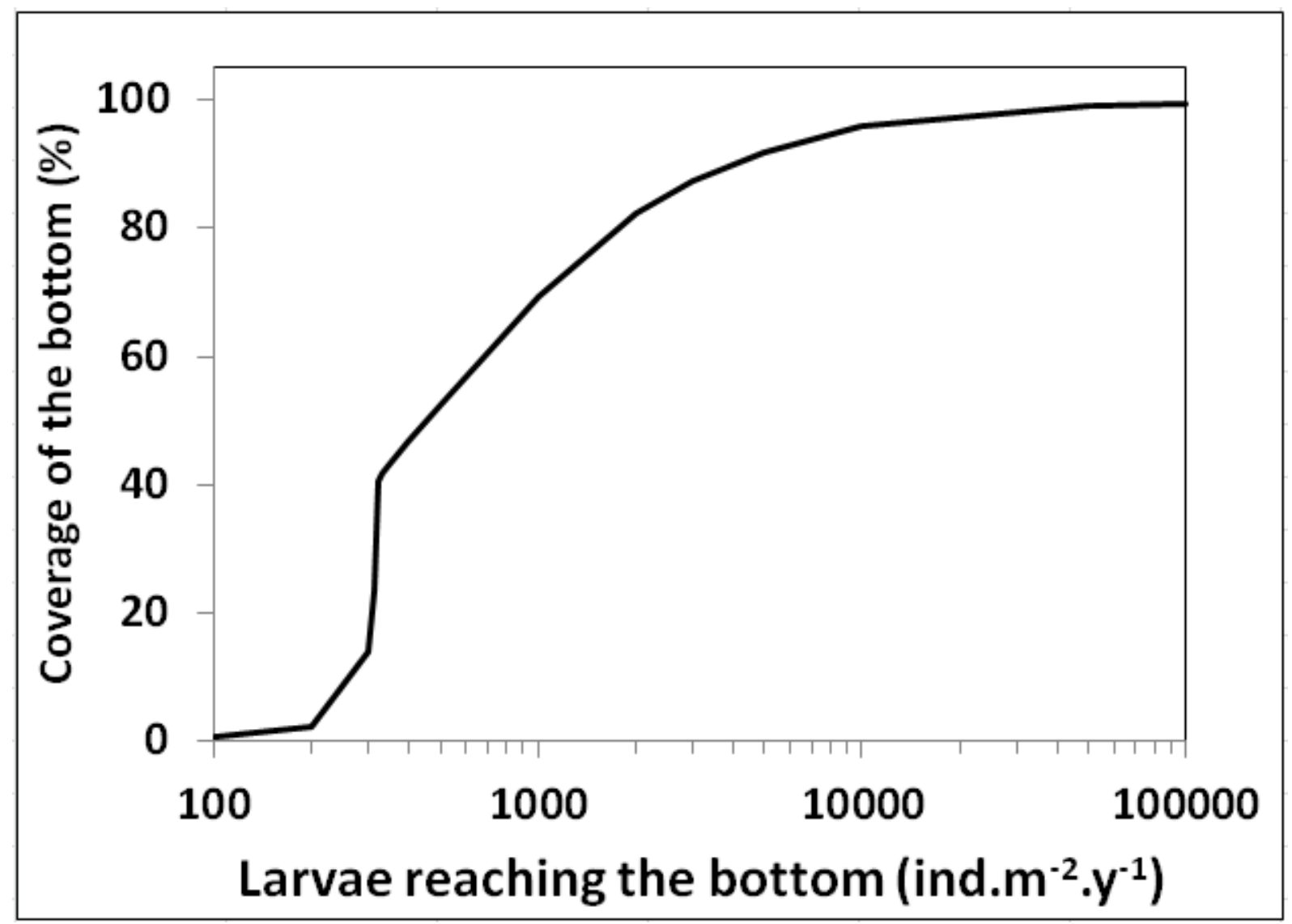

Figure 4 


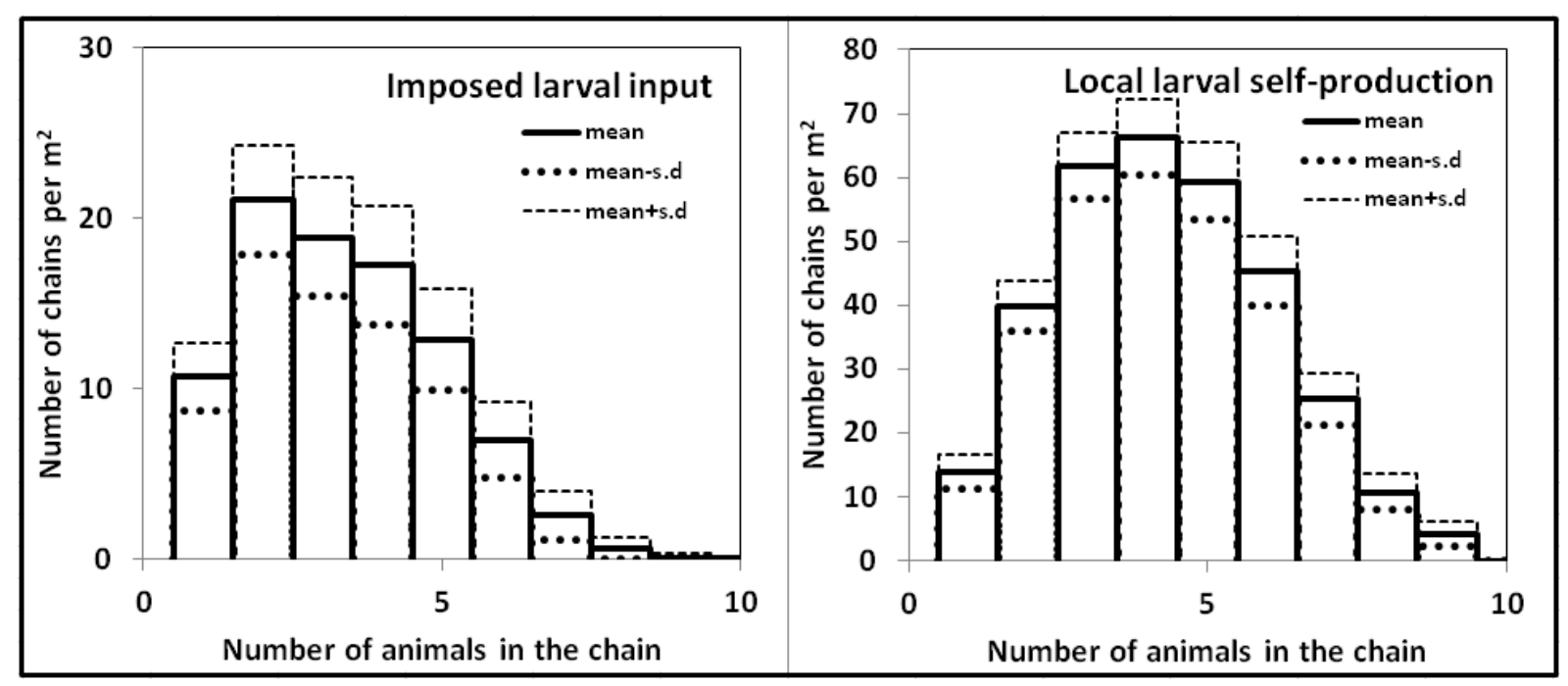

Figure 5 


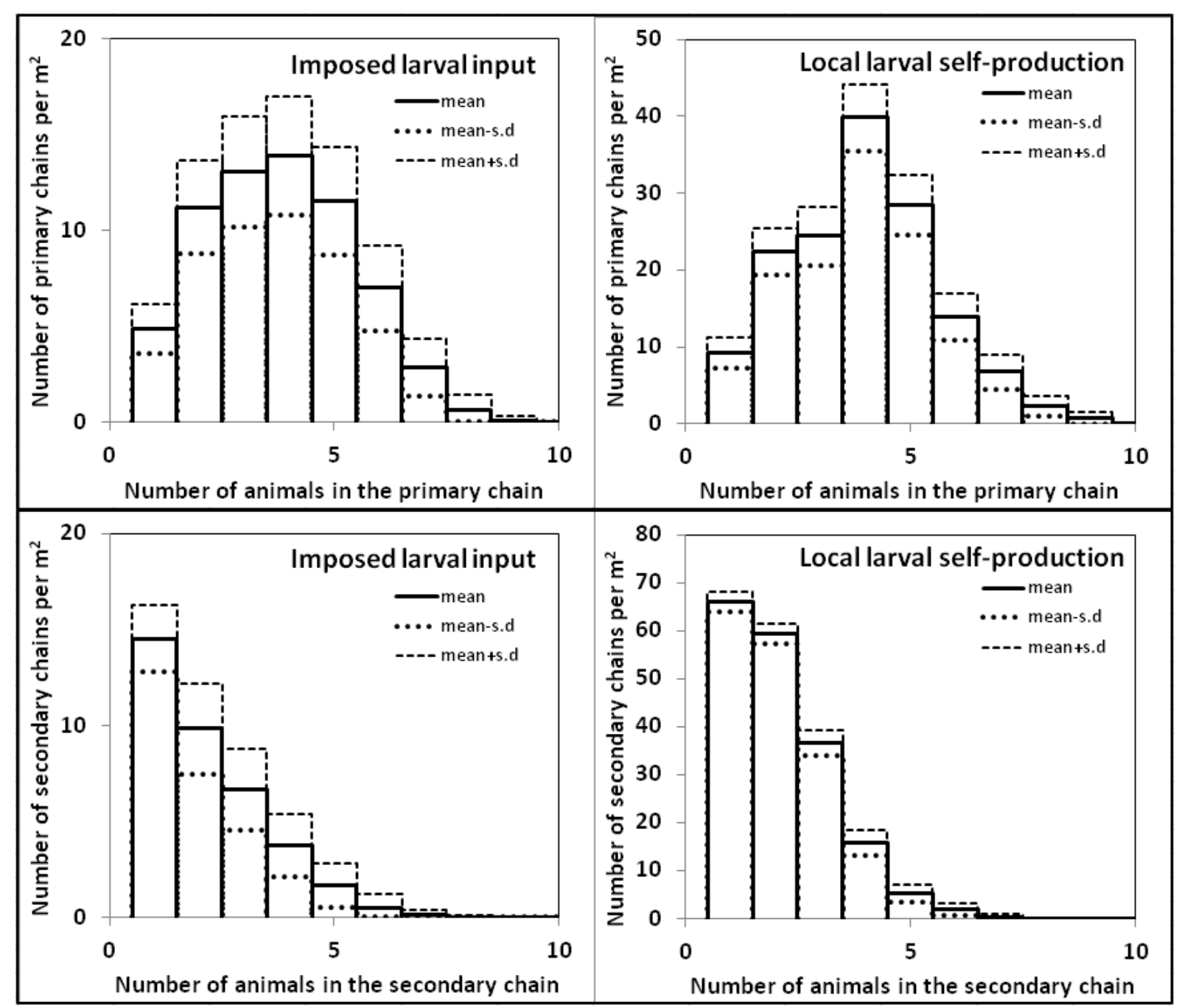

Figure 6 


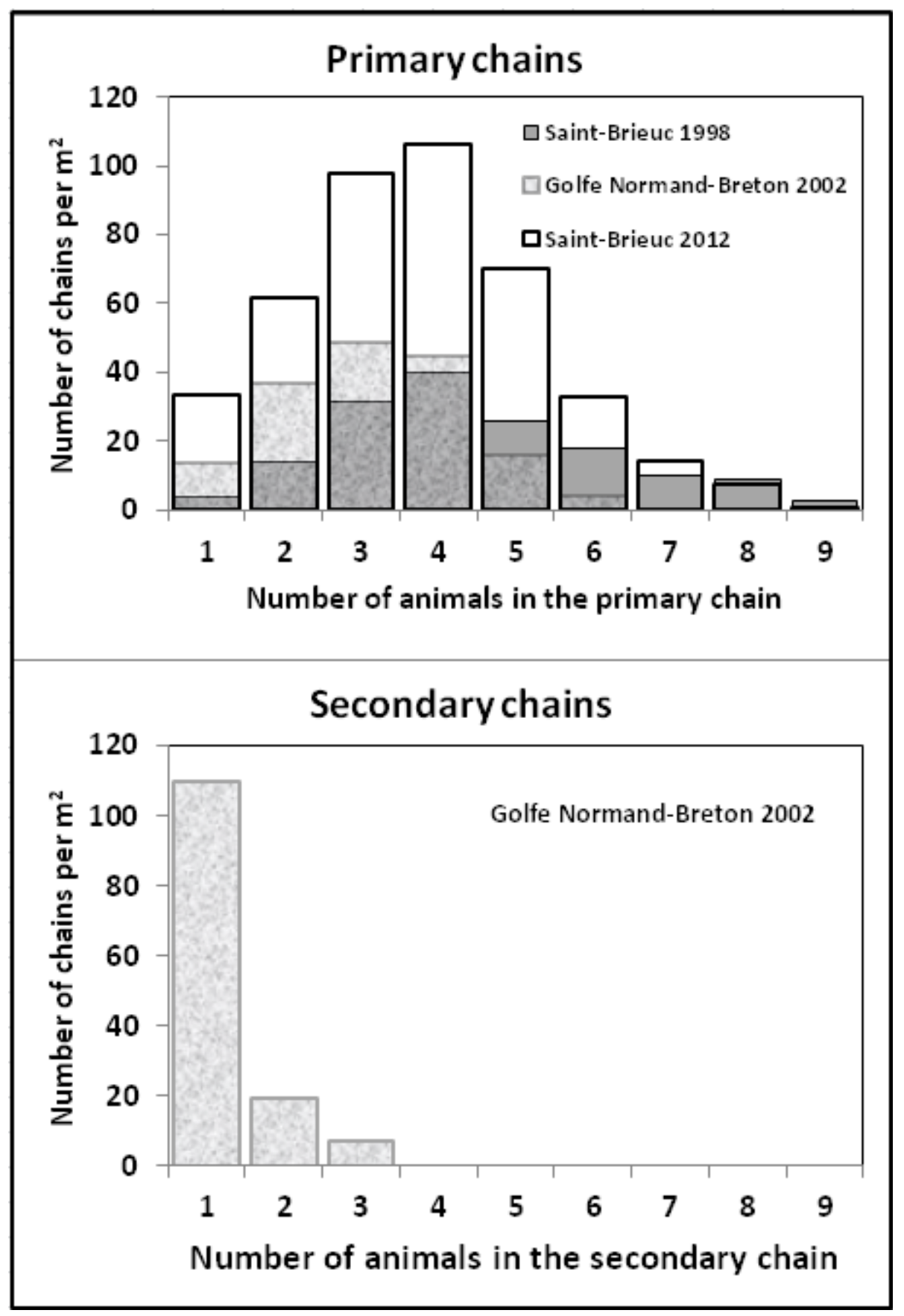

Figure 7 


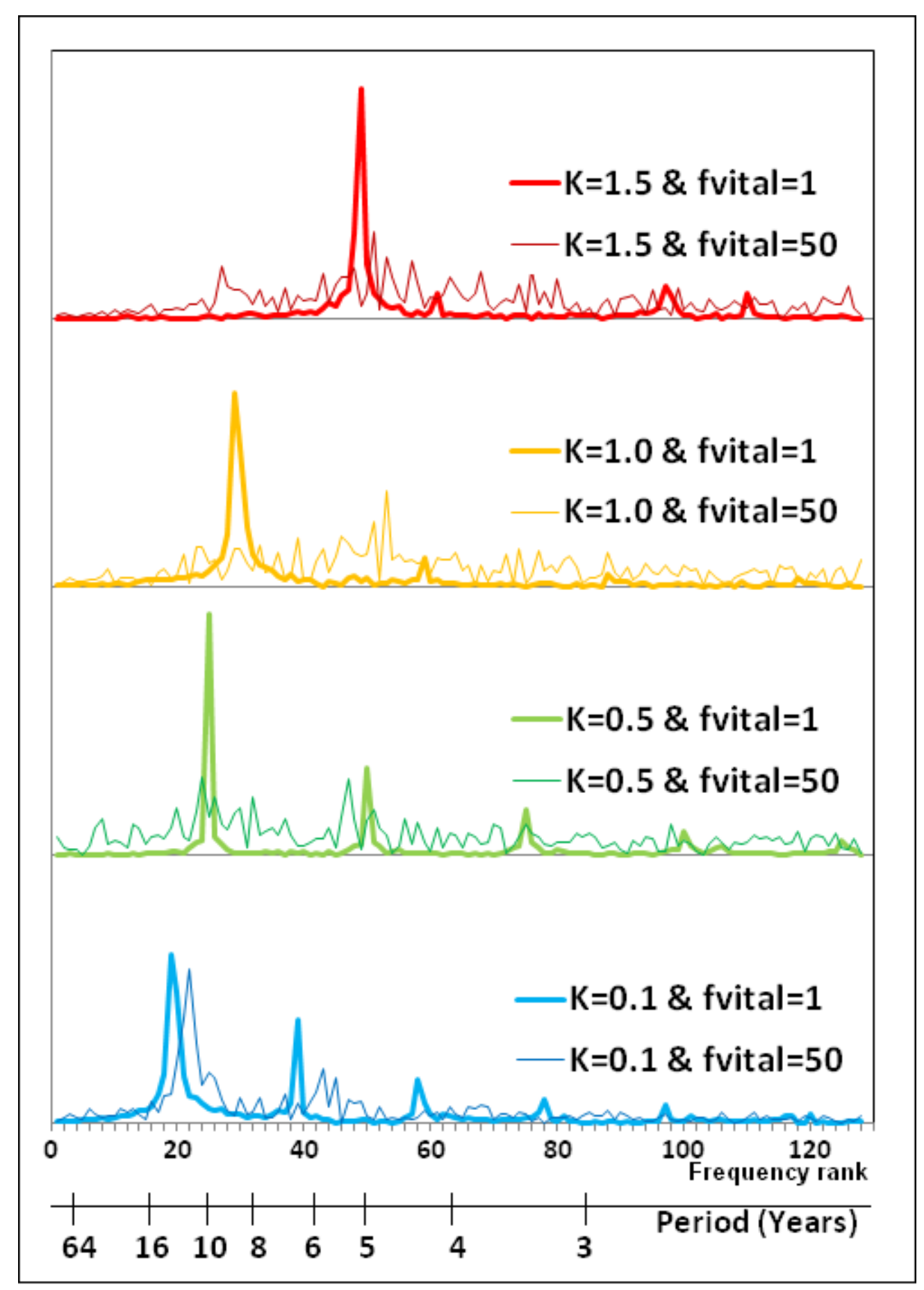

Figure 8 


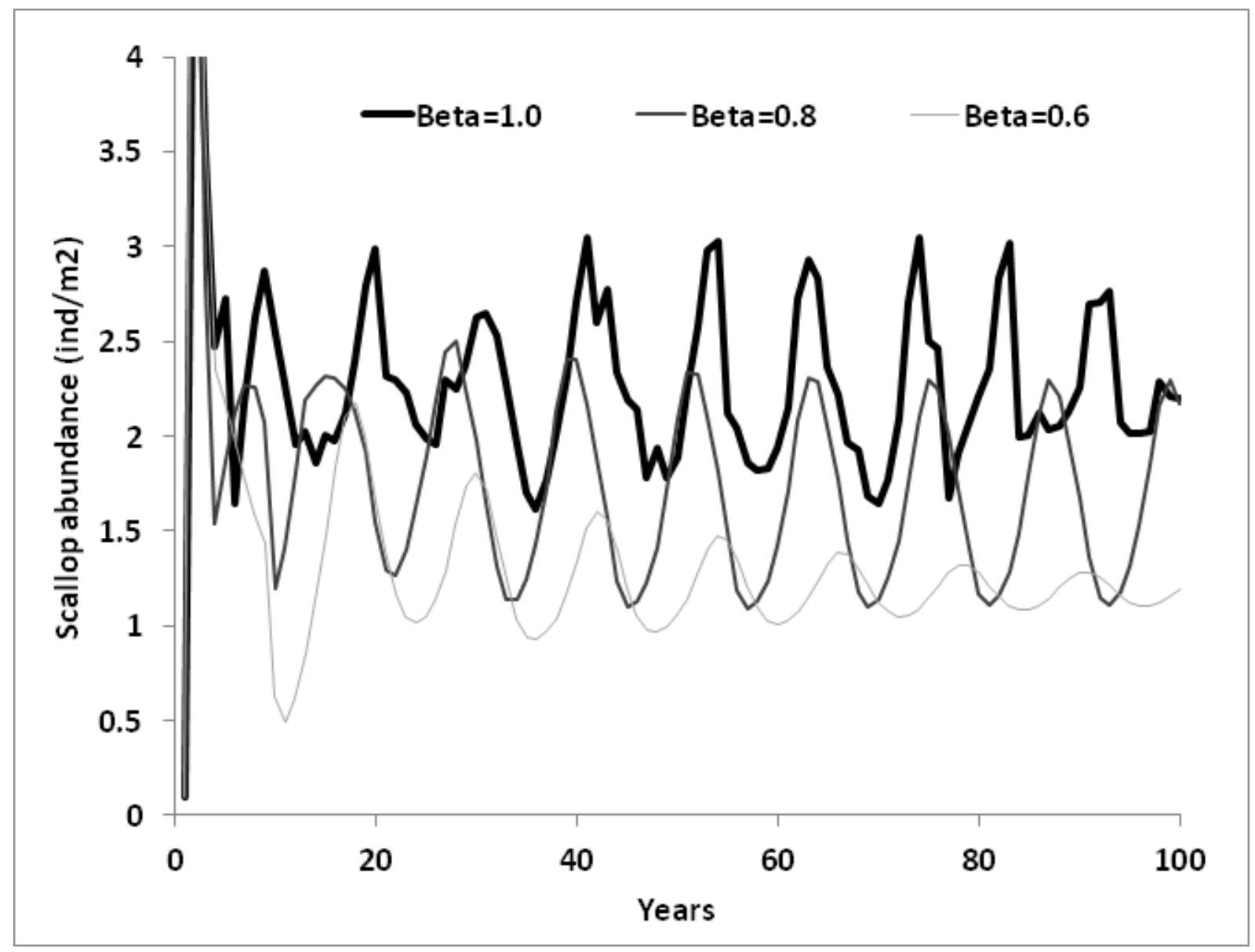

Figure 9 


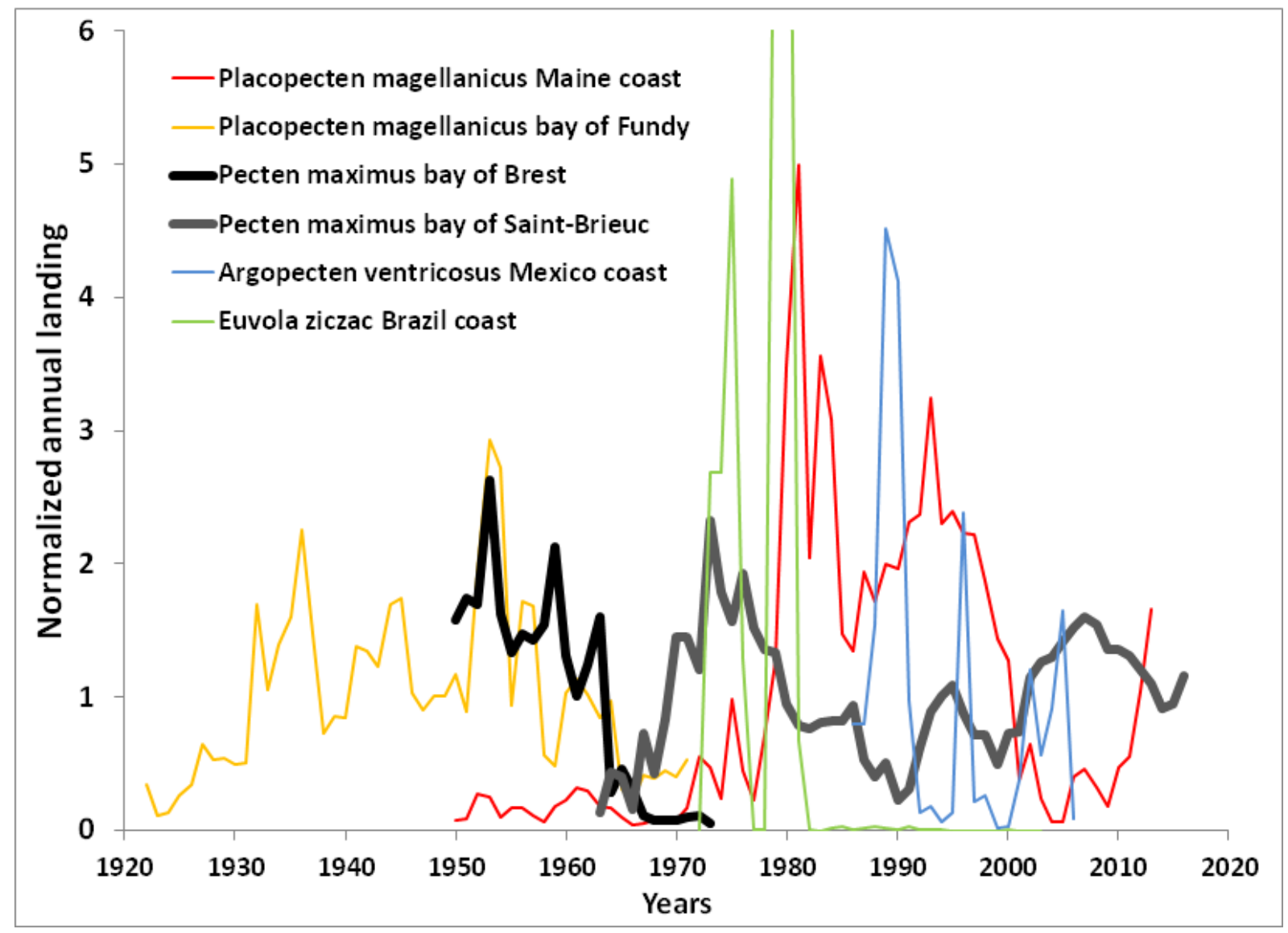

Figure 10 